\title{
A la sombra del latin lover: Antonio Moreno en el cine de Hollywood de los años veinte
}

El caso de The Temptress (Fred Niblo, 1926)

\section{Rocío Alcala Del Olmo Olea}

\section{OpenEdition}

Journals

\section{Edición electrónica}

URL: http://journals.openedition.org/agedor/4037

DOI: 10.4000 /agedor.4037

ISSN: 2104-3353

\section{Editor}

Laboratoire LISAA

Referencia electrónica

Rocío Alcala Del Olmo Olea, «A la sombra del latin lover: Antonio Moreno en el cine de Hollywood de los años veinte », L'Âge d'or [En línea], 1 | 2008, Publicado el 01 junio 2008, consultado el 18 junio 2020. URL : http://journals.openedition.org/agedor/4037 ; DOI : https://doi.org/10.4000/agedor.4037

Este documento fue generado automáticamente el 18 junio 2020.

L'Âge d'or. Images dans le monde ibérique et ibéricoaméricain 


\title{
A la sombra del latin lover: Antonio Moreno en el cine de Hollywood de los años veinte
}

\author{
El caso de The Temptress (Fred Niblo, 1926)
}

Rocío Alcala Del Olmo Olea

\section{Introducción}

1 Durante la década de $1920^{1}$, la carrera cinematográfica de la estrella española Antonio Moreno alcanzó su cenit interpretando la figura cinematográfica del latin lover². Moreno, al igual que estrellas como Rodolfo Valentino, Ramón Novarro y Ricardo Cortez, consiguióincorporarse al star system norteamericano, encarnando un estereotipo sexual que pretendía reconstruir y estructurar el significado de género, en un momento caracterizado por el cambio y la crisis de determinados valores. Su construcción implicaba el choque cultural entre los deseos que la Era del Jazz estaba prometiendo a las mujeres - libertad, movilidad social y sexual - y los códigos de moral tradicional sobre los que se sustentaba hasta entonces la identidad nacional estadounidense. No obstante, el modelo transgresor de masculinidad que el estereotipo proponía quedaba claramente justificado por la alteridad étnica que se le asignaba. Su otredad no pretendía ser un retrato del otro, el latino, sino una búsqueda por definir la identidad nacional norteamericana a través de lo que uno no es: un ser puramente sexual, un "hot blooded".

2 Tomando como punto de partida las ideas expuestas por Richard Dyer en su libro Las estrellas cinematográficas ${ }^{3}$, en este artículo pretendo analizar cómo ha sido estructurada la imagen estelar de Antonio Moreno atendiendo al estereotipo que encarnó y el discurso de género y raza que ambos, estereotipo y estrella, sostenían.

3 El concepto de estrellato implica una dualidad entre el actor y el personaje que permite definir a la estrella como la combinación de personaje fílmico y personalidad fuera de la pantalla. En este sentido, como señala Edgar Morin: “Una vez ha terminado la película, 
el actor se vuelve a convertir en un actor, el personaje sigue siendo un personaje, pero de su unión nace una criatura compuesta que participa de los dos: la star"4. En ambos niveles, el de su vida profesional y personal, la estrella cumple pues, una función esencialmente ideológica que, según Dyer, consiste en preservar el status quo y, por tanto, el poder de la ideología dominante. Salvo en casos excepcionales, la imagen de la estrella representa una tentativa de encauzar, encubrir o desplazar algunas contradicciones inherentes a los valores hegemónicos. Por todo esto, las estrellas son imágenes complejas que contienen significados múltiples en el seno de la cultura que los produce y de la cultura fílmica en la que se inscriben. Su imagen es una polisemia estructurada en torno a una serie de contradicciones, cuya descodificación está condicionada por la potenciación de ciertos aspectos de la imagen y la supresión de otros. Estas contradicciones son por su propia naturaleza de carácter social. La imagen individual de la estrella ofrece un foco adecuado para analizar un conjunto de temas que reverberan en la sociedad como conjunto: éxito, riqueza, amor, comportamiento social aceptable y consumo, entre otros. Esto no quiere decir que la imagen de una estrella en concreto refleje los deseos ocultos de una sociedad, pero como polisemias estructuradas, las estrellas constituyen un discurso social y estético.

El estudio detallado de la imagen estelar de Moreno nos permitirá comprender cómo la estrella no es tanto un fiel reflejo de esa ideología dominante, sino más bien la representación de las paradojas y contradicciones inherentes a la cultura que lo produce. En la imagen fílmica y pública del latin lover Moreno, estas contradicciones implican nociones de raza, género y clase que a continuación analizaremos teniendo en cuenta el marco socio-histórico en el que se inscribe su estrellato.

5 Acerca de estas cuestiones, y de otras colaterales, versará este artículo. En primer lugar, trataré de esbozar los rasgos que definieron la imagen de la star y cómo éstos se complementaron con los del estereotipo; y en segundo lugar, analizaré el tipo de masculinidad representada por el latin lover Moreno, en el film The temptress (La tierra de todos, Fred Niblo, 1926).

6 Antes de comenzar a examinar los rasgos comunes que comparten estrella y estereotipo, hemos de matizar que la figura cinematográfica del latin lover encuentra sus raíces en el mito del Don Juan. Aunque las recreaciones de este mito moderno nos abruman tanto cuantitativa como cualitativamente, y podemos hablar de tantos Don Juanes como adaptaciones literarias existen, el latin lover se nutre de todos ellos $5^{5}$. De la unión entre seducción, burla y transgresión y de su vinculación a un contexto histórico determinado surge un personaje que se regenera con el propósito de conectar y expresar los problemas de una época, y en cuya reelaboración nos encontramos con múltiples interpretaciones o lecturas distintas e incluso contradictorias. Entre estas lecturas, hallamos un Don Juan espectacularizado: el latin lover, prototipo del heroísmo negativo y distanciado del libertinaje, la osadía, el orgullo y la locuacidad que posee el propio mito en sus funciones básicas. Pudiendo estar más próximo al Don Juan de Byron, pues es más bien el seducido que el seductor, pero sin ese toque burlesco y picaresco, y aun lejos de ser el libertino personaje autor de seducciones despiadadas, el burlador burlado de Tirso de Molina, el amante romántico de Zorrilla, el torturador y llorón de Unamuno, el latin lover conserva el planteamiento inicial de todos ellos, la puesta en escena de un discurso basado en los entresijos del amor y el destino.

7 Si bien el destino trágico y la soledad del burlado son cualidades del mito que retoma la industria hollywoodiense en la representación del latin lover, su reformulación tan 
peculiar responde a una relectura del personaje mítico que conecta con ciertas preocupaciones de la época. Además, dadas las características visuales del cine, especialmente del cine mudo, lo verbal queda en segundo plano en beneficio del aspecto visual, centrándose en la fascinación del cuerpo y la mirada que propone esta figura en su representación.

\section{La estrella y su doble naturaleza: Antonio Moreno star/ latin lover}

Desde el momento en que el actor alcanzó la fama, su imagen como star se construyó casi exclusivamente pensando en el estereotipo que representaba. De este modo, los rasgos que definieron la imagen del galán estaban organizados en torno a temas de amor, belleza, consumo y éxito.

El ideal de amor que Antonio Moreno promovía en sucesivas entrevistas y actos promocionales era correlato de las historias de amor que protagonizaba. La mayoría de películas en las que aparecía postulaban un tipo de amor que se instauraba en un terreno de litigio permanente donde el sufrimiento era el motor que movía a amar y en las que se observaba una idealización del amor romántico, un deseo de que los conflictos quedasen sin resolver, que concluía en la mayoría de los casos con la muerte del héroe. Frente al ideal de amor de los happy endings, que normalmente culminaban con boda, la mayoría de tramas protagonizadas por el actor se solían resolver con la separación de los amantes, ya que, según las convenciones del cine clásico, su posición social o su pertenencia a un grupo étnico distinto no les permitía casarse.

Fotografía 1. Antonio Moreno y Greta Garbo en The Temptress (1926, Fred Niblo)

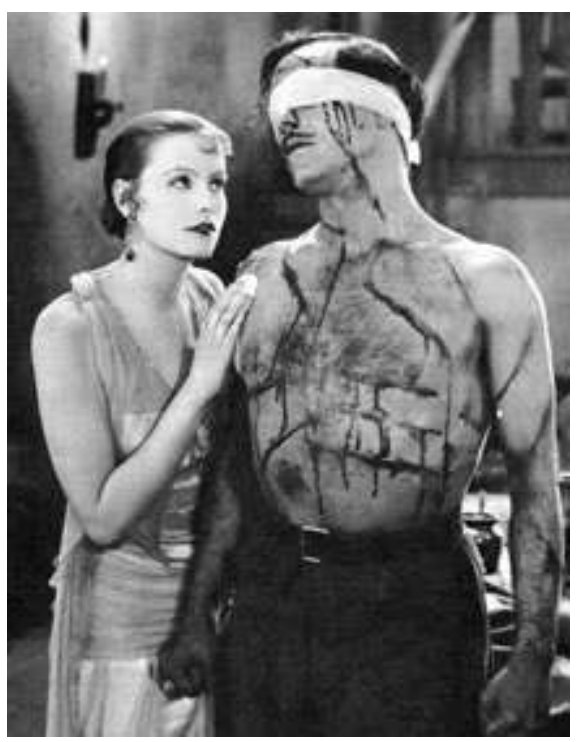


Fotografía 2. Antonio Moreno y Alice Terry en Mare Nostrum (1926, Rex Ingram)

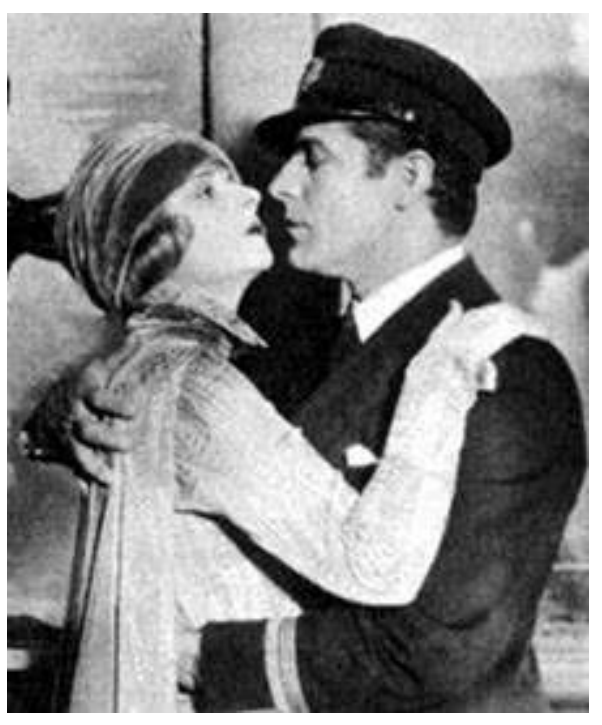

En estos relatos el cortejo caminaba al unísono con ciertos rituales sadomasoquistas en los que el latin lover Moreno participaba en repetitivas prácticas de seducción y rechazo, de auto-humillación y deseo oprimido. Eran pocas las películas en las que no aparecía el látigo como elemento esencial del atrezzo o en las que el espectador no se complacía contemplando las torturas infligidas al latin lover. De esta manera, el discurso de seducción propuesto por el estereotipo articulaba un discurso étnico y racial específico que caracterizaba al latin lover como ser meramente sexual, excéntrico, primitivo e irracional. De modo que una categoría de este tipo no era únicamente una manera de recibir información sobre el otro, el latino, sino un método para controlar lo que parecía ser una amenaza desde una perspectiva tradicional e integrar las perversiones que no se satisfacían en el romance de género ${ }^{6}$. En este sentido, como señala Edward Said ${ }^{7} 7$, refiriéndose a Oriente en su categoría de otro inventada por Occidente, la otredad del latin lover se debe entender tanto como una proyección de los miedos y deseos de Estados Unidos, como el medio por el cual su país creador se define a sí mismo. El otro es el enemigo, puesto que es en el proceso de su lucha contra aquél que Estados Unidos se va creando una imagen identitaria, aunque ésta sea falsa ya que excluye a lo diferente.

11 Las propias declaraciones e incluso la vida privada de Moreno parecían ser una continuación de las aventuras de "Don Juan" que interpretaba. Como el mismo Moreno afirmaba: "Para disfrutar profundamente del amour, éste ha de ser cuestión de vida o muerte" ${ }^{\prime \prime}$ y es por ello por lo que este héroe en la pantalla se vio en la mayoría de los casos transportado por una avasalladora pasión hacia un destino trágico, sugiriéndose así la relación del amor con la muerte. Con respecto a su condición de seductor, cabría destacar que la misma estrella defendía que su forma de amar la había aprendido en su país natal. Paralelamente, el actor se distanciaba del modelo de cortejo y de masculinidad americana con afirmaciones como éstas: "Algunas personas dicen en América: 'Cuando usted quiera conocer a un hombre como él es, juegue con él al póquer'. En España decimos: 'Obsérvelo en un affaire"”.

Por otra parte, el discurso de amor y la atracción romántica que proponía la estrella y el estereotipo dialogaban con el ideal de belleza ambigua y dual que ambos vertebraban. La belleza funcionaba como medio erótico a través del cual se asentaba un 
modelo de atracción masculina que preservaba y otorgaba continuidad a la alteridad sexual y étnica del estereotipo. Como defiende Gaylyn Studlar, en los films de latin lovers, concretamente en los interpretados por la estrella Rodolfo Valentino: "los discursos sexuales que combinaron la belleza del cuerpo masculino con la otredad étnica/racial estaban ya siendo inscritos en la cultura popular dirigida a las mujeres" ${ }^{10} 10$. Se trataba de trascender la jerarquía de sujeto/objeto de deseo socialmente impuesto desde un discurso basado en la diferencia sexual y, para ello, se elaboraba un modelo de belleza fundado en la ambigüedad sexual de su apariencia: ojos rasgados, cabellos engominados, movimientos delicados se unían a miradas penetrantes y agresivas, a cigarros y puros consumidos audazmente que evidenciaban una belleza frágil al tiempo que robusta y varonil.

Fotografía 3. Una belleza frágil al tiempo que robusta y varonil

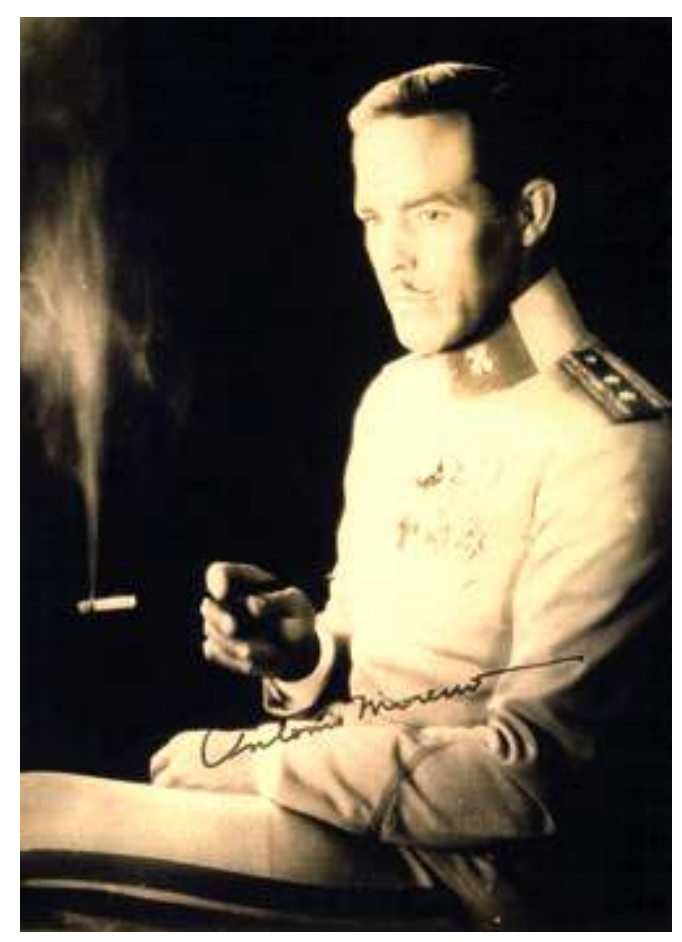


Fotografía 4. Una belleza frágil al tiempo que robusta y varonil

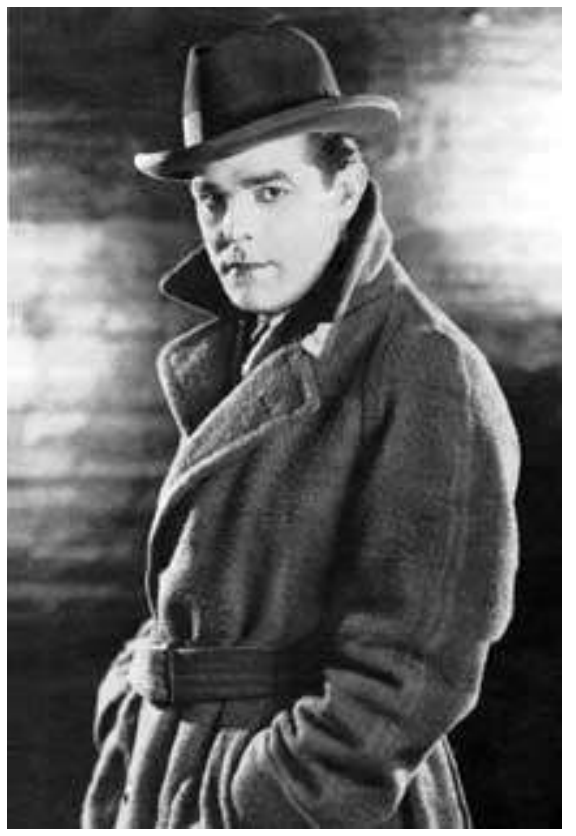

13 En sus películas, Antonio Moreno aparecía en numerosas ocasiones con camisas rasgadas que permitían ver su torso musculoso; también, destacaban las escenas en las que se describía con cierta sensualidad el propio acto de vestir del personaje que interpretaba, así como múltiples planos de detalle de su espalda musculosa y sus manos refinadas. A dicha ambigüedad sexual contribuía el uso constante de trajes y máscaras y la ubicación del personaje en escenarios exóticos - desiertos, plazas de toros, cantinas y tabernas - de países juzgados tales por el cine norteamericano como Argentina o España.

Fotografía 5. Antonio Moreno y Pola Negri en The Spanish Dancer (Herbert Brenon, 1923)

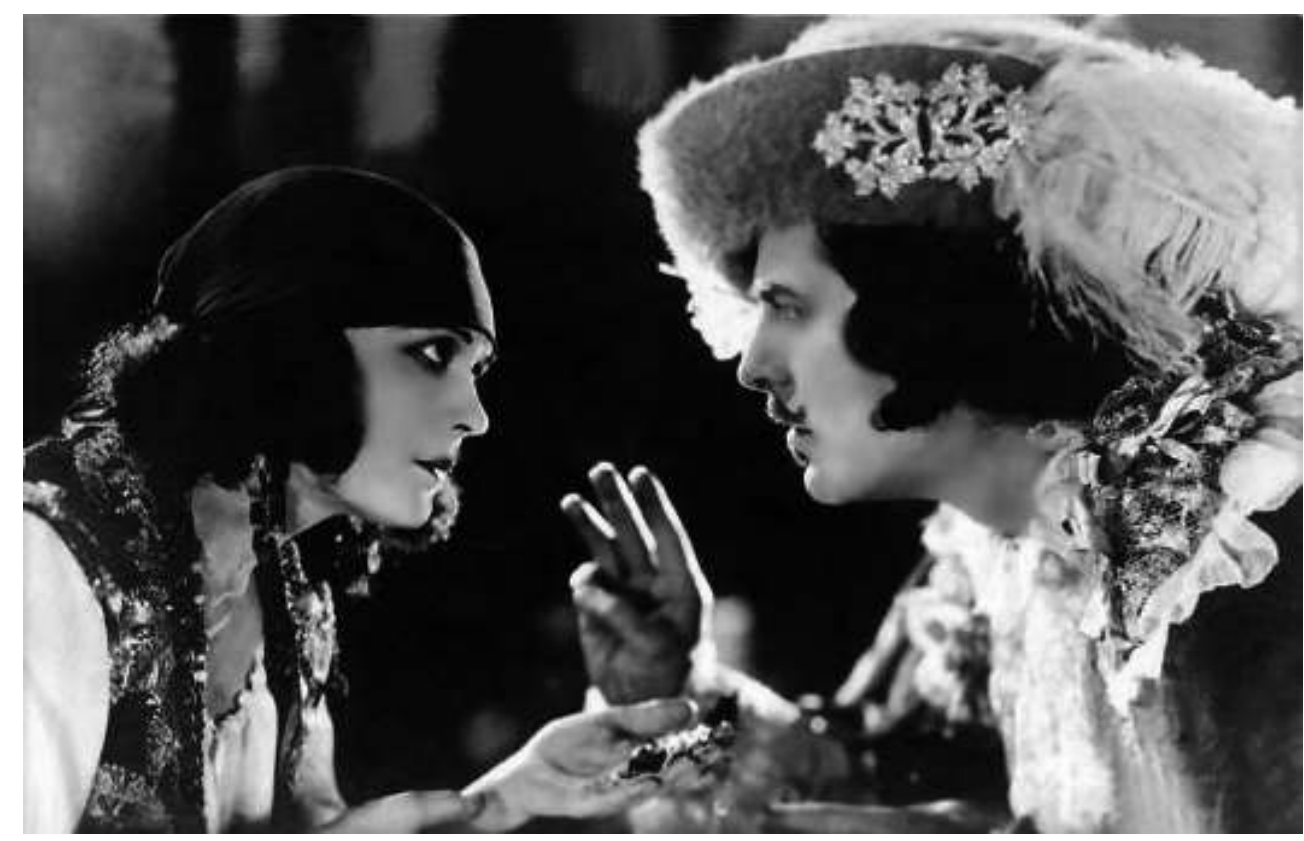


14 La belleza ambigua del latin lover caminaba pareja con la apariencia física de Moreno. Las fotografías en las que aparecía la star mostraban, por un lado, una masculinidad viril que se ponía de manifiesto en su mirada agresiva y, por otro, una masculinidad afeminada connotada a través de los trajes exóticos con los que se fotografiaba. Studlar describe así una fotografía que acompaña a un artículo en la revista Motion Picture Magazine en 1919: "Moreno lleva un pareo de cachemira y luce un pendiente pirata. Su cabeza está cubierta por un turbante. Un brazo desnudo y musculoso está amenazadoramente flexionado, su puño está apretado y sus ojos miran de soslayo como si observara una amenaza desconocida. Así, 'la feminidad' potencial de su traje es rebajada por su mirada agresiva y masculina y la tensión de sus músculos" ${ }^{11}$.

Fotografía 6. 'The lure of the flesh', en palabras de Adele Rogers.

Photoplay, marzo de 1924

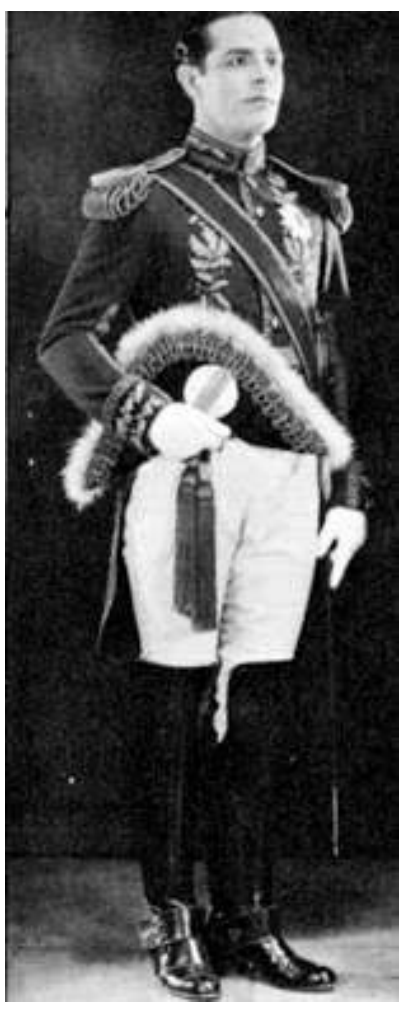


Fotografía 7. 'The lure of the flesh', en palabras de Adele Rogers. Photoplay, marzo de 1924

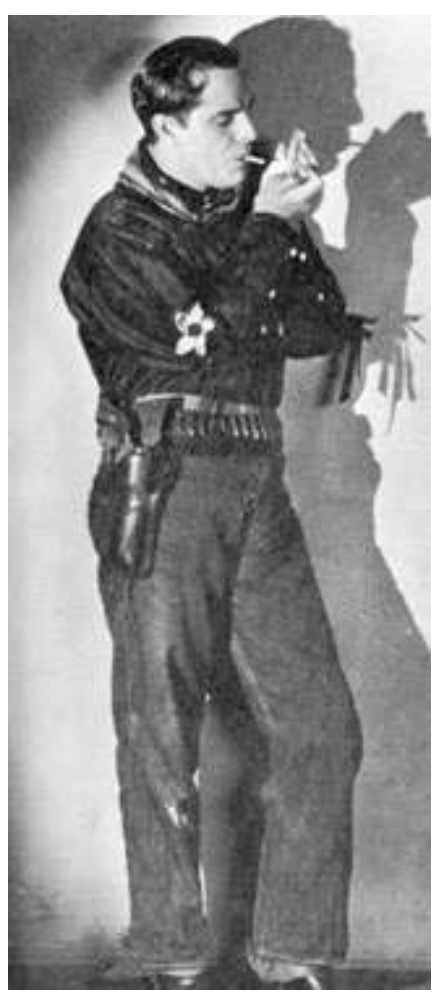

Fotografía 8. 'The lure of the flesh', en palabras de Adele Rogers. Photoplay, marzo de 1924

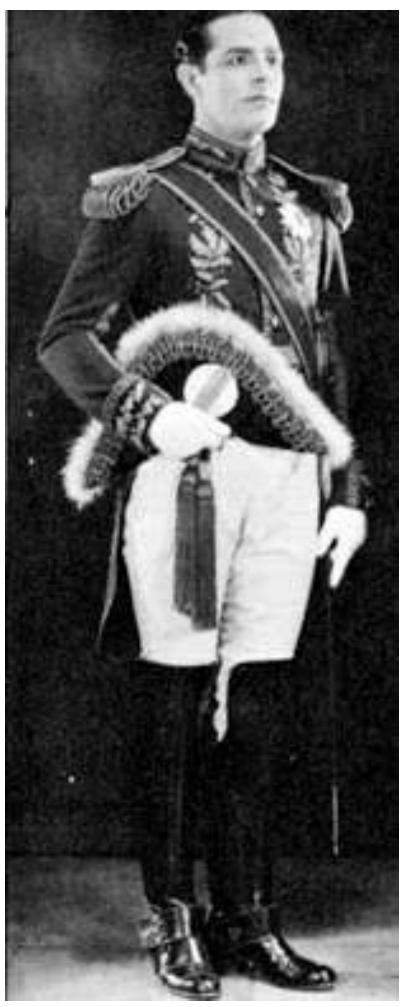

15 Simultáneamente, la polaridad sexual que poseía esta nueva belleza masculina venía acompañada de un discurso insólito y contradictorio sobre el culto al cuerpo masculino. 
Insólito, ya que la carga de erotismo que llevaba implícita dicha imagen inauguró una nueva manera de representar el cuerpo masculino que el resto de héroes cinematográficos del momento, el espadachín o el acróbata, habían disimulado en la abstracción de la velocidad, mostrando un cuerpo sexualmente aséptico ${ }^{12}$, y contradictorio, puesto que, por una parte, conectaba con el tipo de belleza masculina de la época ${ }^{13}$, a saber, el joven bello, fuerte y puro al que se le asociaban las ideas de vitalidad, disciplina e inocencia; y, por otra, proponía un cuerpo que realzaba la espiritualidad vulnerable y las ideas "efébicas y de esteta afeminado" ${ }^{14}$. Estos últimos se consideraban ideales transgresores que habían tratado de ser asociados al hombre decimonónico decadente (entre otros, a la figura del dandy) para evitar su proliferación.

16 A su vez, este tipo de belleza y su plasmación en la pantalla carecía de identidad nacional. Aunque conservaba ciertos rasgos asociados al prototipo del dandy inglés o del flaneur francés culturizado ${ }^{15}$, fundamentalmente se trataba de una construcción imaginaria que carecía de referente real. Como ha expuesto el pensador Antonio Gramsci ${ }^{16}$, en cualquier sociedad no autoritaria las formas culturales y las ideas que transmiten pueden ser más influyentes que las que se promueve desde la sociedad política (instituciones estatales, ejército, policía y burocracia central) cuya función dentro del Estado es la dominación directa. En este sentido, dicha construcción imaginaria forma parte de lo que podríamos llamar "latinismo", haciendo referencia al término orientalismo acuñado por Edward Said, es decir, una invención americana, un discurso de poder más que un discurso verídico sobre Latinoamérica que proponía al latino adoptar rasgos de otras culturas si quería alcanzar el éxito.

En el discurso publicitario, el carácter étnico de Moreno fue acentuado al mismo tiempo que enmascarado. La belleza del actor se interpretaba como algo exótico y fascinante, pero también como diferencia socio-cultural amenazante, que debía dulcificarse después de las polémicas que la imagen afeminada de la estrella Rodolfo Valentino había suscitado. De forma paralela, su imagen se reproducía en carteles publicitarios, fotografías en revistas de fans que, o bien ensalzaban las implicaciones sexuales potencialmente relacionadas con sus orígenes étnicos hispanos ${ }^{17}$, o bien trataban de americanizar su imagen. En este sentido, se justificaba su condición de galán a través de retratos de perfil que acentuaban su mirada seductora y, paralelamente, se americanizaba su imagen con fotografías en las que Moreno aparecía disfrazado con trajes deportivos, adecuándose al estereotipo del atleta norteamericano del momento. Por ejemplo, en una entrevista realizada por la periodista Joan Jordan, para la revista Photoplay en 1921, la autora realizaba preguntas afirmativas como: "Tu método de amar es estrictamente continental, ¿verdad? ¿Has aprendido a saber lo que quiere una mujer en España, o es puro instinto?"; y posteriormente apelaba a su blancura:

Su blancura, incluso la de sus dientes, me deslumbró por un momento y sus ojos negros grandes

- ojos como los que tienen esos niños italianos en las calles de Nueva York brillaban como su sonrisa al mismo tiempo que calentaban su corazón. ${ }^{18}$ 
Fotografía 9. Tratando de "americanizar" su imagen. Photoplay, noviembre de 1920

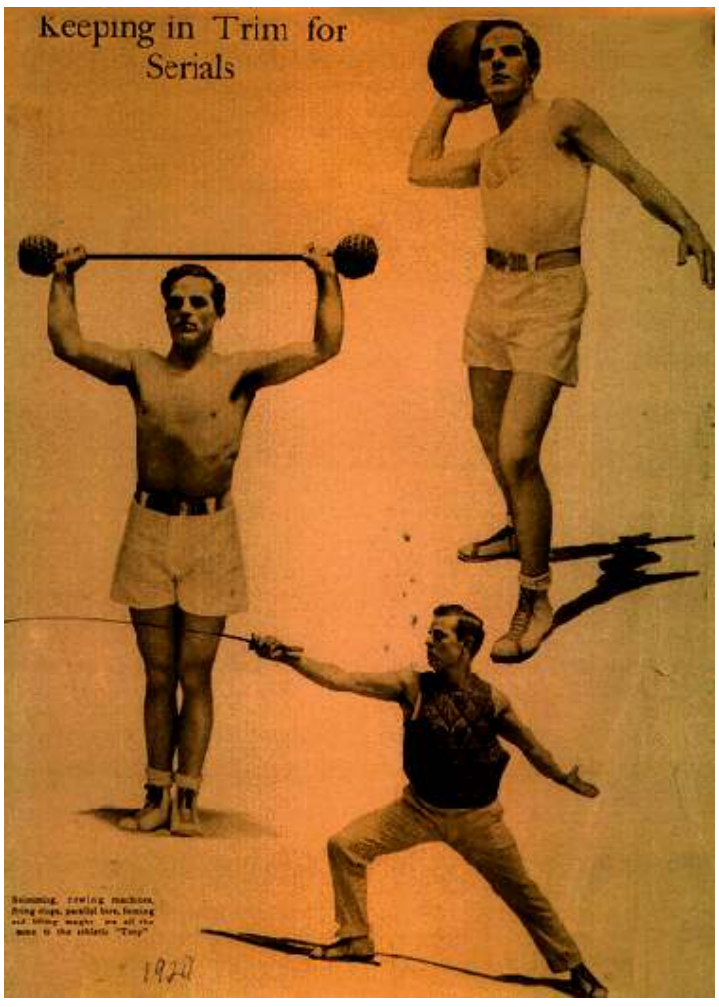

Fotografía 10. Tratando de "americanizar" su imagen. Photoplay, noviembre de 1920

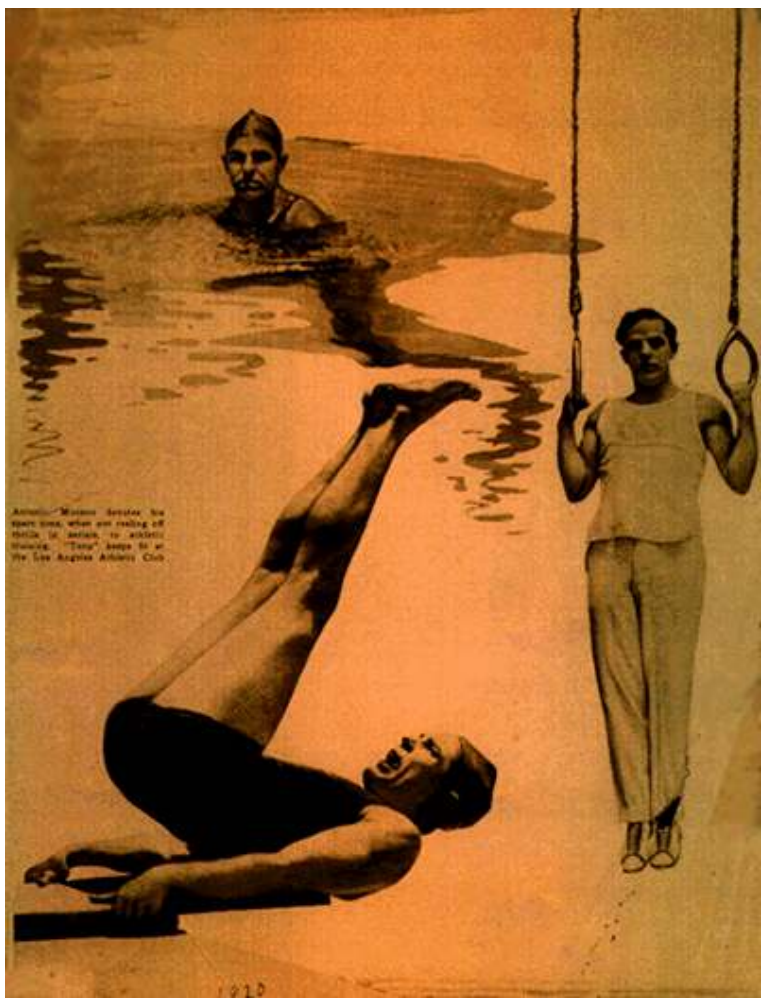

18 Desde el punto de vista de su recepción, esta belleza ambigua fue interpretada desde dos perspectivas antagónicas que realzaban la alteridad étnica asignada tanto al 
estereotipo como a la star. Por una parte, se reconocía su diferencia étnica de forma exótica ${ }^{19}$ o fetichista, es decir, lo racial formaba parte del erotismo del estereotipo; por otra, se le concedía el calificativo de "flaperooster" o "Power Puff" ${ }^{20}$, pues de dicha belleza dual se tomaba la parte afeminada entendiéndola como una amenaza al modelo de masculinidad americana del momento. En un artículo de Photoplay, Adele Rogers lo explicaba así: "sus ojos pequeños, su nariz plana y su gigante boca, no se pueden medir con los estándares de belleza masculina aceptados generalmente en este país" ${ }^{21}$.

Fotografía 11. "La boca y la barbilla pertenecen a un tipo nacido en un país que es famoso por hacer salvaje lo salvaje", Chicago Daily Tribune, 4 marzo de 1923, p. 29.

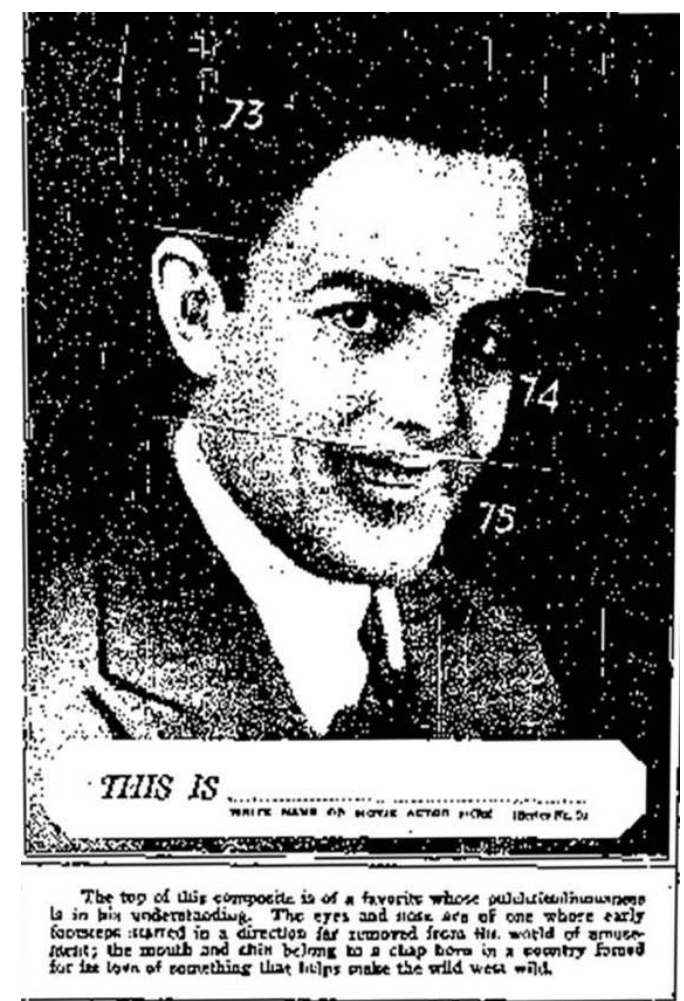

Recopilando todo lo dicho, la imagen pública de la star se erigió sobre la misma ambigüedad desde la que se construyó el estereotipo que interpretaba. Antonio Moreno poseía una belleza exótica con rasgos mediterráneos y occidentales que se identificaba con la del seductor latino. Asimismo, sobre su imagen se articulaba un discurso de amor que funcionaba en sentido contrario al de una economía social encargada de encauzar las energías emocionales creando ataduras familiares. En suma, la imagen del latin lover Moreno se constituyó como una imagen formada y fácilmente reconocible de cómo una sociedad se ve a sí misma a través de su otro (externo e interno).

\section{Ecos socio-culturales de la imagen pública de la star y de su estereotipo}

El análisis pormenorizado de las representaciones de la star y su estereotipo no sólo nos permite entender los temores y las fantasías que un país como Estados Unidos proyecta, sobre otro que se perfila como antagónico, sino también desentrañar algunas de las claves de las estrategias de definición de la propia identidad nacional estadounidense. 
Por este motivo, resulta interesante examinar el armazón cultural y el momento histórico en el que alcanzó la fama Moreno. Ciertos factores históricos, demográficos y sociales explican el discurso sexual y racial específico que articuló el latin lover, pues como veremos "la efectividad del estereotipo reside en la manera en que invoca el consenso" ${ }^{22}$. Es importante, por tanto, ubicar la imagen de la estrella y la de su estereotipo en su correspondiente contexto histórico, pues precisamente la emergencia de ambos se debió a la incorporación de la mujer a la economía de consumo.

21 Aunque la década de los veinte no puede separarse por corte radical de la anterior, ésta estuvo marcada por una serie de cambios considerables. Fue una época de prosperidad, caracterizada por la consolidación de la economía de consumo y la explosión definitiva de la cultura de masas. El auge económico que se vivía en estos años permitió cierta transformación en las costumbres y las reglas dominantes de antes de la Primera Guerra Mundial.

Una de las imágenes más importantes de este periodo fue sin duda la de la Nueva Mujer $^{23}$. Aunque los síntomas de esta nueva mujer habían comenzado a manifestarse varios años antes, durante la década se produjeron una serie de transformaciones que posibilitaron cambios en la vida de las mujeres en el ámbito laboral, político, familiar y en el propio consumo. En estos años eran notorias las campañas por la igualdad de los derechos entre hombres y mujeres. Además, la aprobación en 1920 de la XIX Enmienda Constitucional concedió el derecho al voto de las mujeres blancas. En el ámbito laboral, fue convirtiéndose en algo socialmente aceptable el hecho de que las jóvenes trabajaran antes de casarse. Las mujeres comenzaron a experimentar mayores libertades que fueron objeto de debate político y, al mismo tiempo, esa aparente libertad femenina fue utilizada como estrategia comercial para acrecentar el consumo. Muy sintomáticamente un economista, en 1929, titulaba su artículo "El ama de casa como compradora y controladora del consumo" ${ }^{24}$. Ventiladores, frigoríficos y planchas se hicieron de uso general para las mujeres. Simultáneamente, este nuevo tipo de consumo trajo consigo la comercialización de nuevos hábitos sociales. Las mujeres gastaron más de 1500 millones de dólares anualmente en productos de belleza publicitados por la radio. Algunas se lanzaron en contra de las normas de apariencia victoriana: se cortaron el pelo, desecharon los corsés y optaron por trajes que recibían el calificativo de 'el oriental' o 'el egipcio' $25^{25}$. En el ámbito familiar, el cambio fue más notable, pues se consolidó un tipo de familia en la que la mujer no sólo asumía el rol de ama de casa, sino también el papel de compradora y contable.

Acorde con esta coyuntura, Hollywood comprendió que la espectadora femenina era una fuente de ingresos considerable. A medida que transcurrió la década, el porcentaje de mujeres que acudieron al cine se fue incrementando hasta llegar en 1927 a constituir el 83 \%. De hecho, una proporción muy alta de películas producidas fueron melodramas y romances. Así pues, del mismo modo que se ofrecía un nuevo tipo de belleza femenina y un nuevo estilo de vida, Hollywood creó un tipo de hombre, el amante ambivalente (seductor y seducido, sujeto y objeto de deseo) que promovía la reconciliación entre viejos y nuevos valores emergentes en esos años y canalizaba ciertas tensiones que amenazaban el sistema. Aunque su comportamiento y su estilo parecieran poner en entredicho el tradicional modelo de masculinidad americana, el latin lover representaba en el fondo una negociación hegemónica que posibilitó la introducción de nuevas ideas pero que reafirmó conceptos básicos para mantener el sistema patriarcal. 
Fotografía 12. Harold Teen nunca estuvo hecho para ser un latin lover. Chicago Daily Tribune, 19 de junio de 1926; p. 16.

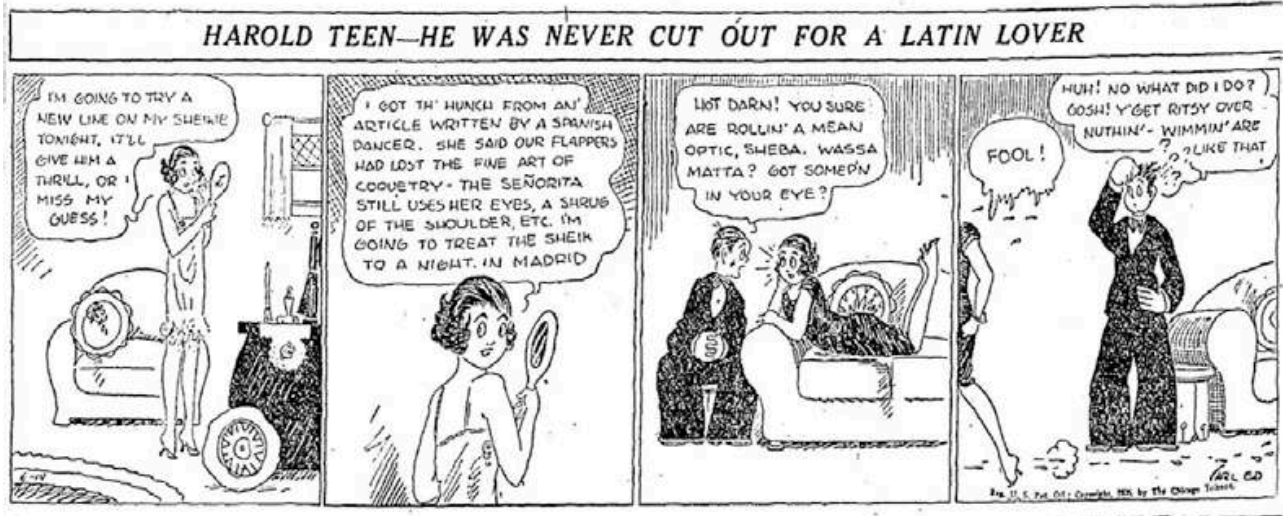

Las confesiones de Moreno a la prensa revelan el tipo de reconciliación que modulaba su alteridad sexual. El hecho de que en ocasiones declarase públicamente su rechazo a la nueva mujer de los años veinte ${ }^{26} ; \mathrm{y}$ en otras, al contrario, mostrara su aprobación a ciertos hábitos, los menos peligrosos para el sistema, pone de manifiesto la función principal que define el estereotipo del latin lover (y a sus estrellas) como figura promotora de cierto consenso. En este consenso se organizaban diferentes estrategias económicas, políticas e ideológicas que evidencian cómo la aparente transgresión sexual que proponía tanto el estereotipo como la estrella fue creada por y para su otro antagonista: la mujer consumista de los años veinte, un tipo de mujer que encontró en el consumo gran parte del papel activo que en la mayoría de los casos no tuvo en la política o en el ámbito social.

Asimismo, la función performativa de su alteridad sexual se traslada a su representación como otro étnico y cultural. Moreno representaba a un otro étnico imaginario que oscilaba entre la admiración y el desprecio, y al que se le atribuyeron caracteres contradictorios: cualidades que subrayaban su diferencia étnica y rasgos que conectaban con cierta política de negociación y asimilación a la cultura dominante, curiosamente en un momento histórico donde el debate sobre la inmigración empezaba a tomar un tono xenófobo tras haber fracasado el intento de 'americanizar' a los inmigrantes recientemente llegados.

El derrumbamiento del internacionalismo wilsoniano y la llegada a la Casa Blanca de Calvin Coolidge, defensor de los valores tradicionales, produjo un recrudecimiento del nacionalismo coercitivo de tiempos de guerra. La intolerancia, haciéndose pasar por patriotismo, creció y el chovinismo condujo a la persecución de minorías políticas y étnicas (socialistas, bolcheviques y judíos, entre otros). Tratando de estabilizar la composición étnica de la población estadounidense, se tomaron medidas legales que imponían restricciones cuantitativas a la inmigración procedente de Europa. En estos años, el flujo migratorio procedía mayoritariamente del sur y este de Europa (Italia, Polonia, Albania, Hungría, Rumanía y Lituania). En el caso de los latinos, exceptuando a los mexicanos, el número total de latinoamericanos censados ni siquiera llegaba a constituir el $1.1 \%$ del total de la población norteamericana. El flujo masivo de inmigración de dicho perfil aún no se había producido.

En este clima xenófobo, Hollywood actuó buscando la reconciliación, es decir, proponiendo la figura del latin lover y la de sus estrellas como "hombres románticos que conseguían casarse con mujeres blancas" ${ }^{27}$. De este modo, los personajes interpretados 
por Moreno ponían en escena un tipo étnico que podía asimilarse a la cultura 'blanca' y que no apelaba a ningún grupo inmigrante cuantitativamente importante en el país. Además, su estrellato simbolizaba el mítico sueño americano de ser un inmigrante que huye del Viejo Mundo y se convierte en ídolo americano gracias a su esfuerzo y trabajo incesante. Podemos concluir que la estrella Antonio Moreno representaba a un otro que aceptaba la asimilación y que justificaba su fórmula magistral del melting pot surgida a principios de siglo, que instaba al inmigrante a rechazar sus orígenes étnicos y adoptar la lengua, los principios y la cultura de la sociedad receptora.

\section{Antonio Moreno en The temptress (Fred Niblo, 1926)}

Una vez expuesto el intercambio recíproco de rasgos que definieron a la estrella y al estereotipo y los factores socio-históricos que favorecieron su emergencia, pasaremos a analizar cómo la propia imagen de Moreno como latin lover se reactualiza y se modifica en función del contexto socio-histórico del momento. En este respecto, un ejemplo evidente lo constituye el latin lover que interpreta la estrella en el film The temptress ( $L a$ tierra de todos, Fred Niblo, 1926). El personaje de Robledo expone un modelo de masculinidad oscilante, alejado del latin lover de principios de la década que expresaba sin tapujos su condición de ser fatalmente seducido. Sin embargo, lo que está en juego en esta película es, por una parte, el cuestionamiento, la evaluación y la comprobación de que este tipo de masculinidad únicamente tiene lugar en presencia de la vamp (protagonista femenina) y por otra parte, el reconocimiento de una masculinidad heroica fundada en la acción que sea capaz de reconvertir a la mujer fatal en una mujer maternal. Por último, me centraré en el tipo étnico que representa el personaje de Robledo: un latino occidentalizado que pondera los valores de su país creador (EEUU).

Fotografía 13. Cartel de The temptress (La tierra de todos, Fred Niblo, 1926).

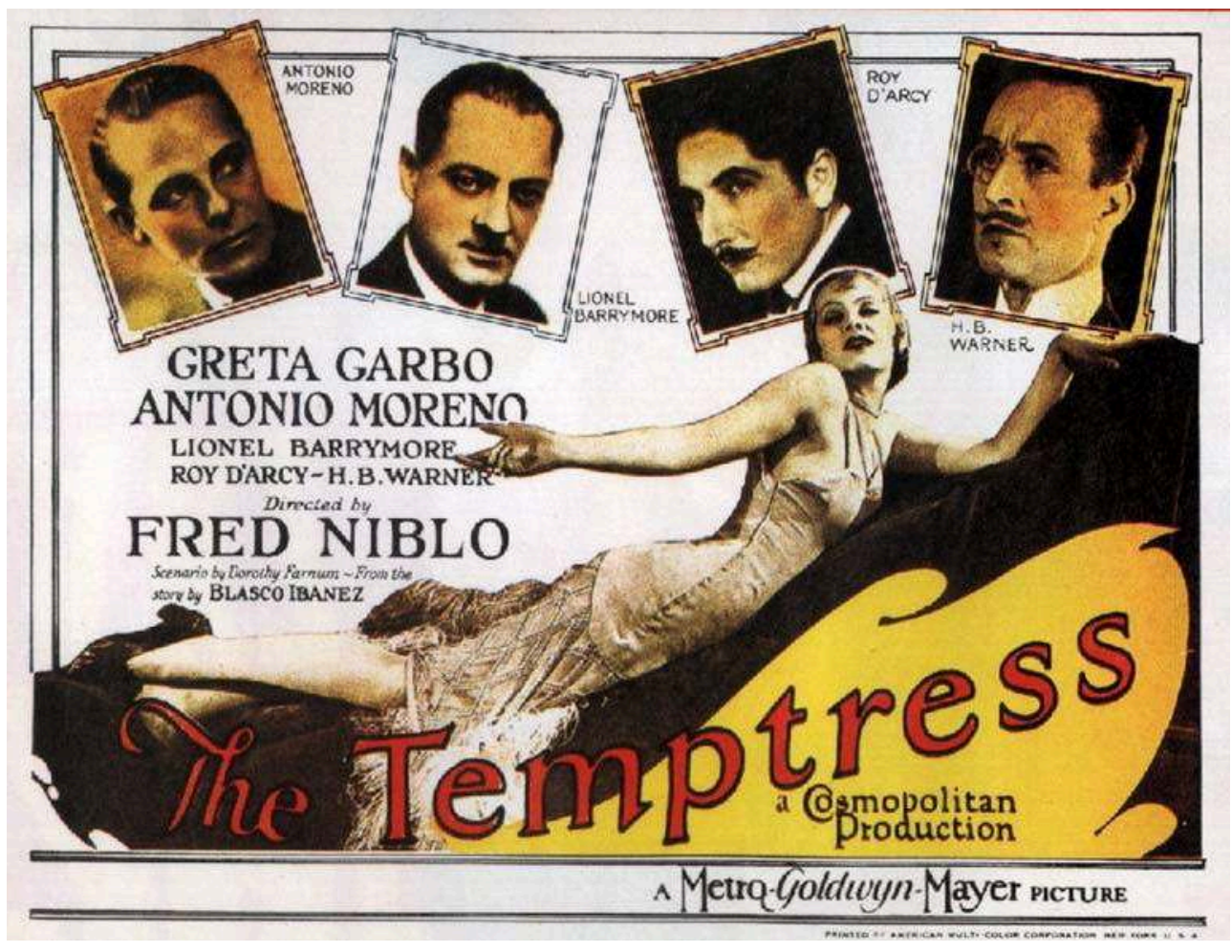

L'Âge d'or, 1 | 2008 
The temptress cuenta el sufrimiento amoroso que experimenta Robledo, un ingeniero español que trabaja en Argentina, tras haberse dado cuenta de que la mujer de sus sueños, Elena (interpretada por Greta Garbo), que había conocido días antes en una fiesta carnavalesca en París, es la mujer de su amigo el marqués de Torre Blanca. Su vuelta a Argentina no reduce su padecer, pues su destino parece estar ligado a Elena. Pasado algún tiempo, ésta convence a su marido para comenzar una nueva vida en Argentina. La llegada de la pareja supone el inicio de las disputas entre todos los amigos, el fin del noviazgo de Robledo con la señorita Celinda y la destrucción del dique en el que el ingeniero estaba trabajando, símbolo del progreso y de años de trabajo de la comunidad. Sumamente arrepentida por todo lo sucedido, Elena decide regresar a París y Robledo se casa con Celinda logrando rehacer su vida. Años más tarde, Robledo acude a París a recibir un homenaje por su trabajo y allí se encuentra inesperadamente con Elena. Completamente deteriorada, ésta no advierte su presencia y el ingeniero se aleja resignándose a olvidarla.

\section{La masculinidad del latin lover (de)construida por su otro, la vamp}

La estructura narrativa del film propone a un héroe que no es sino que se hace a medida que va conociendo la condición femenina. En la secuencia de arranque, se nos presenta a un héroe en fase cero, sin código alguno que contenga sus emociones, pero que va a verse obligado a reconducir su identidad si no quiere que ésta sea destruida por una feminidad diabólica. A la luz de la luna parisina, Robledo encuentra a la mujer de sus sueños, la angelical Elena (interpretada por Greta Garbo), y sin miedo alguno le promete su amor para toda la vida. En estos momentos, Robledo aparece caracterizado como el enamorado ingenuo que confía plenamente en cupido y en un amor que se postula como experiencia mística al margen de la vida terrenal. Pero, como se expresa mediante un intertítulo, este amor noble que se fusiona con el cosmos encuentra su final en la puesta de sol. Se trata de un amor imposible, cuyo límite es precisamente el mundo civilizado que categoriza a la pareja, un mundo donde lo social y lo sexual se legitiman recíprocamente. 
Fotografía 14. El amor romántico y sus fronteras

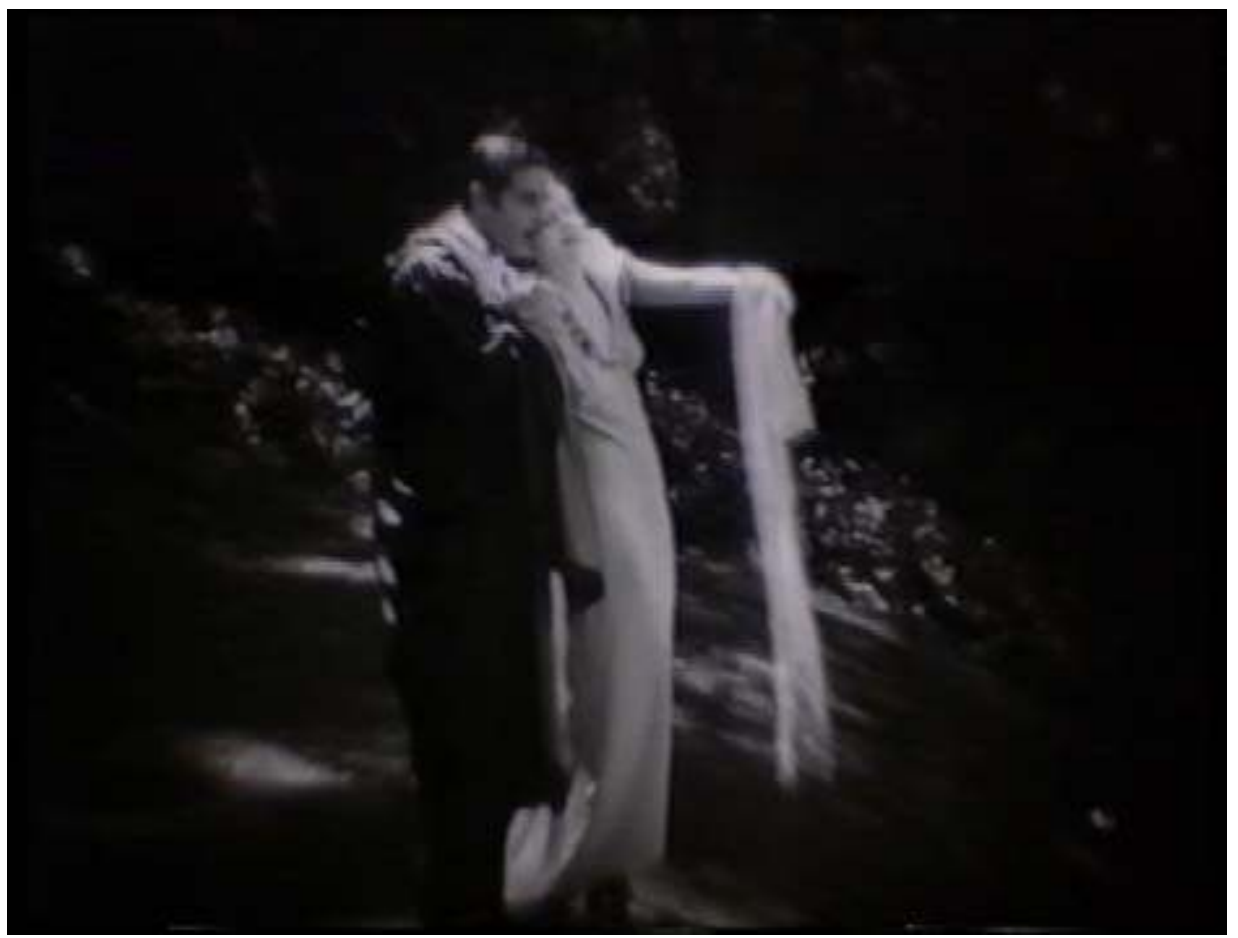

31 Al día siguiente, después de que el ingeniero se dé cuenta que su amada Elena es la esposa de su amigo el marqués, emerge un nuevo Robledo, que oculta su posición de dominado en la esfera sentimental y decide regresar a Argentina para construir su identidad en el ámbito de lo público: el amor fraternal hacia sus amigos, el trabajo honrado y su afán justiciero contra los bandidos. Aunque la expresión abatida de su rostro en la cabina del tren, cuando está a punto de partir, parece anunciar el llanto, ésta funciona como trampolín para el desarrollo de la acción. Acto seguido, Robledo se encuentra en un carro dirigiéndose a la salvaje Argentina. Este país representa para Robledo la rehabilitación de su espíritu heroico fundamentado en la valentía, el liderazgo y la virilidad.

32 A su llegada, el ingeniero es lisonjeado por todo el pueblo. Llama la atención cómo se desarrolla dicho recibimiento. En primer lugar, Robledo saluda a sus viejos amigos y, a continuación, tiene unas breves palabras para la bella Celinda. Si en un primer instante, el encuentro entre Celinda y Robledo parece presagiar un nuevo affaire, segundos después, queda olvidado en el momento en que vemos a un Robledo conmocionado y entristecido mientras reparte a cada amigo sus correspondientes fetiches. De este modo, la historia de amor heterosexual pasa a segundo plano, precisamente, porque Argentina debe ser para el héroe la alcoba del amor fraternal exclusivamente masculino. 
Fotografía 15. Robledo, el héroe del pueblo

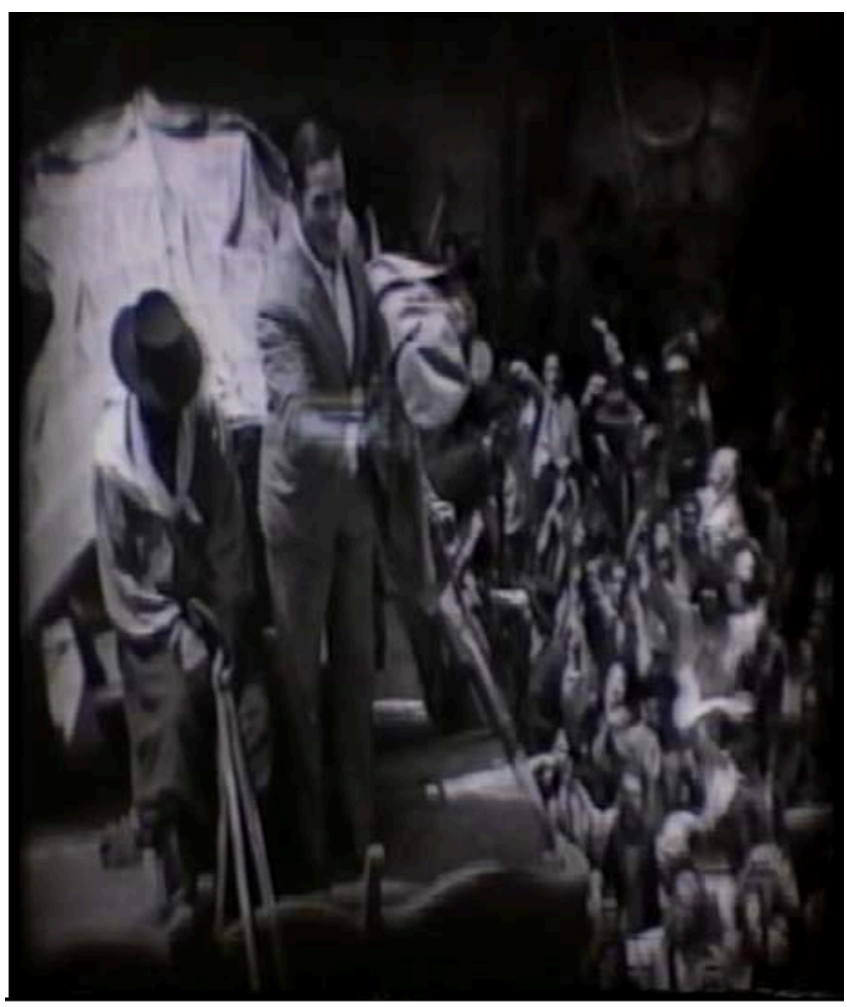

33 Así pues, la "masculinidad" de Robledo emerge de la confidencia y del intercambio de correspondencia con sus amigos. Nos referimos a la secuencia en la que se observa a la comunidad masculina profundamente emocionada y nostálgica. En su excursión al mundo lascivo parisino, Robledo ha recogido cartas y regalos para sus amigos. Mientras los obsequios ofrecidos a las mujeres son tejidos y enseres de lujo, las cartas otorgadas a Canterac y Pirovanni son escritos afectivos que, paradójicamente, ensalzan el carácter racional de estos hombres que han decidido vivir alejados de sus respectivos familiares para poderles ofrecer el dinero que necesitan. La extroversión sentimental que muestran en estos momentos los personajes masculinos es el resorte para la expresión de una masculinidad épica fundamentada en cualidades "masculinas" como la razón, la productividad y que tiende a asociar el sufrimiento con la virilidad, pues cuando éste se deja notar lo hace para elogiar el sentido heroico de dicha retención.

Esta muestra de afectos no debe hacer dudar al espectador de la hombría masculina. En efecto, en la secuencia siguiente Robledo y sus compañeros se encuentran trabajando en la construcción de un dique y aparece el personaje del bandido Manos Duras. La presencia amenazadora del bandido permite observar a un Robledo agresivo y varonil, golpeando la mesa y dejando perfectamente claro cuál es el estilo de vida de él y de los suyos: vivir para trabajar.

Una vez que la condición masculina del protagonista ha quedado asociada a principios como la valentía y la honorabilidad, la llegada inesperada de Elena a Argentina y, consecuentemente, la emergencia del malestar interior del personaje (entre el deber y el deseo) generan un nuevo ciclo que reconduce el viaje inicial de Robledo hacia nuevos horizontes. Sorprendentemente nos encontramos con un héroe cuyo cuerpo deviene puro espectáculo y cuya identidad se forja en la yuxtaposición de los dos tipos de masculinidades - viril y vulnerable - que se habían mostrado como antagónicas. 
Transcurrida la cena en la que el ingeniero rechaza con una gestualidad impenetrable las miradas seductoras de Elena, la presencia de nuevo de Manos Duras y el beso inesperado de éste a la coqueta, provoca un duelo que presagia la abertura de las heridas del héroe y la emergencia de un nuevo Robledo dual (épico pero sentimentalmente herido). Durante la lucha de "gauchos", la figura semidesnuda asume distintas identidades - objeto sexual, héroe admirable, espectáculo -, y transita entre los dos polos - masculino y femenino. En el momento en que Robledo revela su torso, se convierte en objeto erótico sometido a múltiples miradas que exponen la imagen del cuerpo masculino como espectáculo y fuente de placer visual. Su pecho erguido se presenta en un plano picado subjetivo, correspondiente a la mirada de Elena, y en un encuadre que lo sitúa en el centro de la composición dependiente de la mirada del resto de sus amigos. Se trata en este segundo caso de un flirteo de miradas que introduce explícitamente un subtexto homoerótico, un nuevo proceso de mirar masculino que acaba ocultándose bajo el discurso de valor y fortaleza, pues finalmente el héroe afirma que ha luchado para preservar su autoridad.

36 Es importante subrayar que la representación de esta nueva masculinidad que exhibe el cuerpo del héroe como objeto erótico aparece cuando el orden moral y social queda cuestionado por el enemigo. Frente a la condición objetual que en otras películas de principios de década mostraba el latin lover en cualquier ámbito (público y privado), la espectacularización del protagonista exalta el coraje y la hombría de la hazaña heroica, subrayando la conexión entre masculinidad y poder.

Fotografía 16. El cuerpo masculino como fuente de placer visual

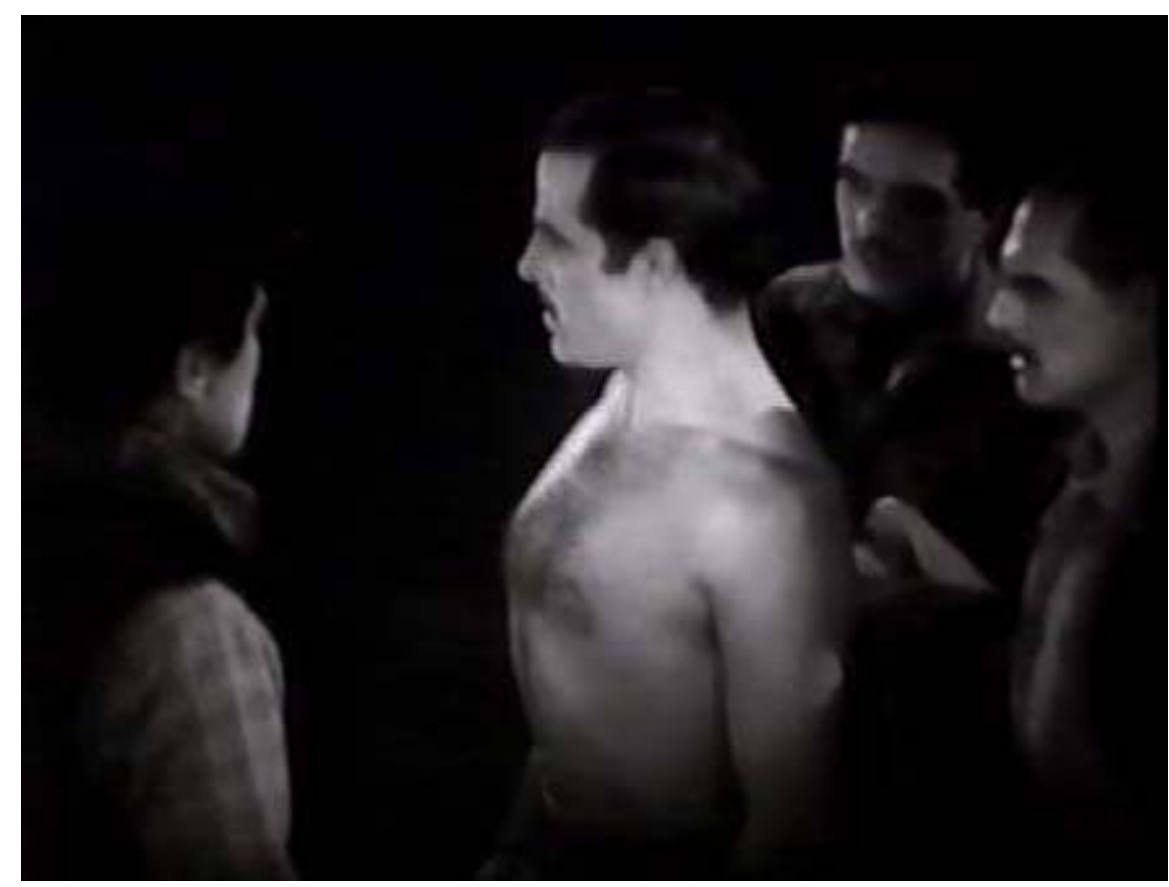

Ya en el hogar, sus heridas comienzan a cicatrizar gracias a Elena, que se las desinfecta con las gasas de su propio vestido. Durante la cura, el cuerpo del ingeniero queda fragmentado en planos de detalle de su mano, rostro y su pecho, que lo convierten, de nuevo, en objeto de deseo y de consumo en un intercambio erótico para Elena y también para el espectador. Al mismo tiempo, la exposición de su cuerpo herido le hace modelo de ciertas fantasías eróticas, en las que el potencial del deseo masoquista 
masculino - en tanto deseo inconsciente de liberarse de la Ley del Padre - desvela su confrontación con una forma de masculinidad viril y agresiva que queda ratificada cuando el ingeniero empuja a la coqueta y declara que ha luchado por el bien y la honra de Argentina.

Fotografía 17. Del placer a la acción

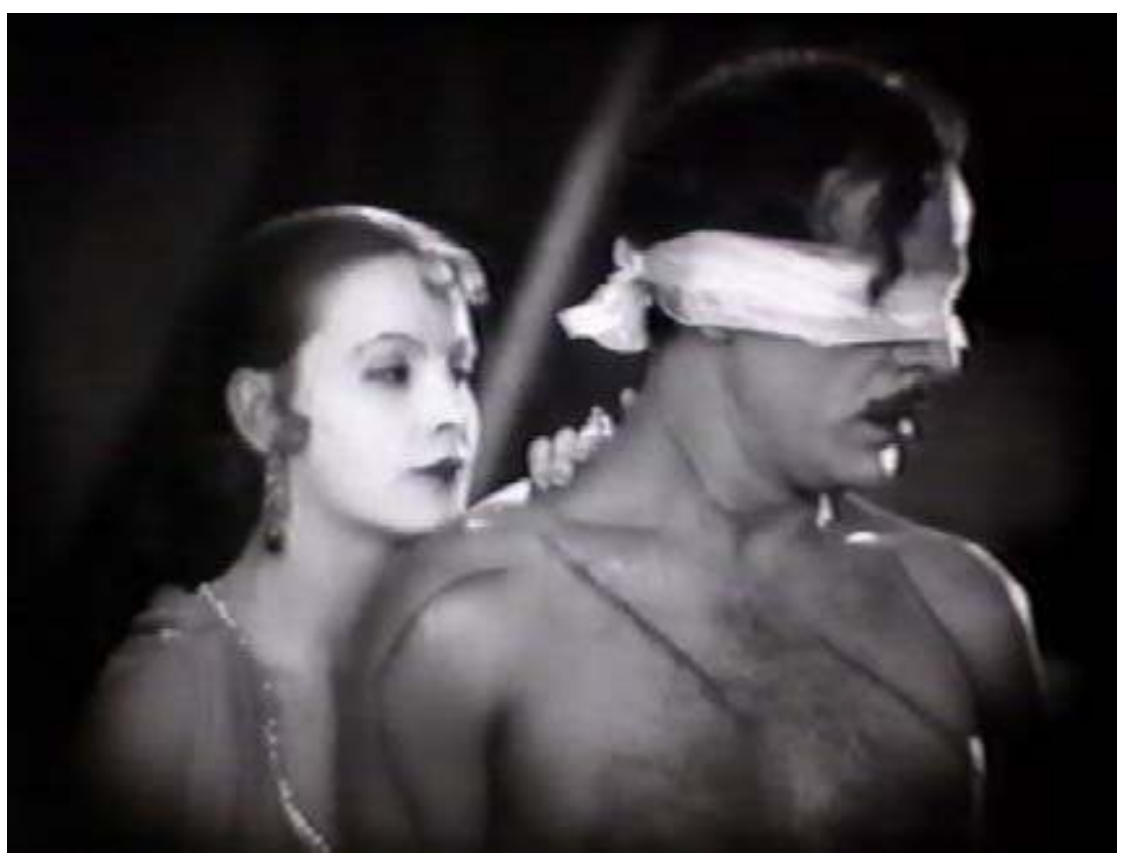

Fotografía 18. Del placer a la acción

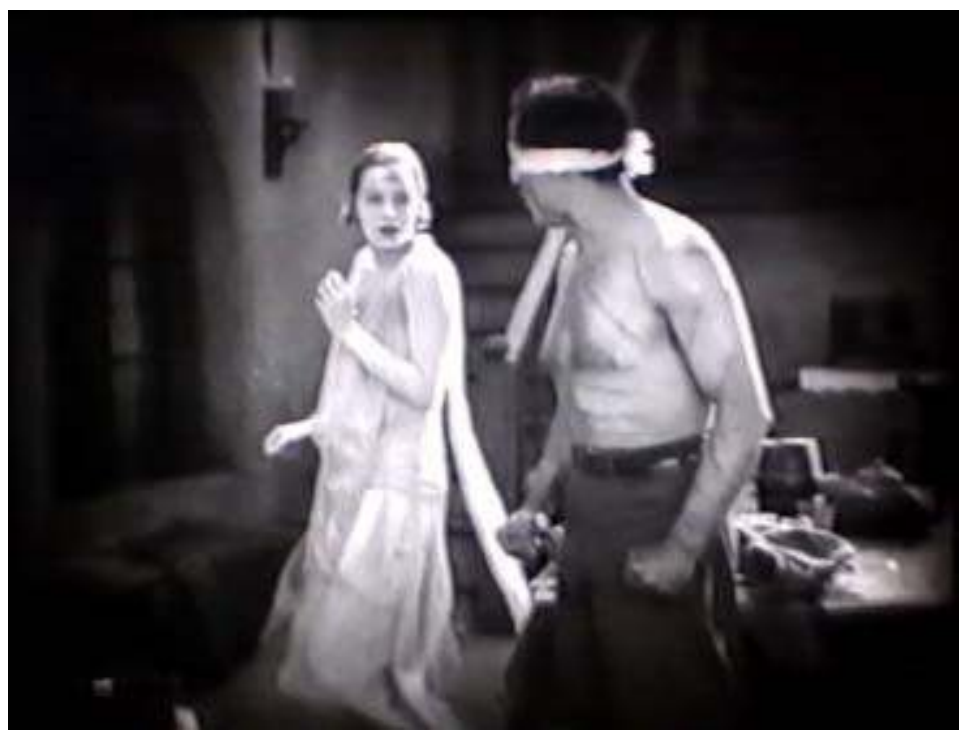

Igualmente, el tipo de feminidad que pone en escena la vamp refuerza las actitudes y comportamientos masculinos que pretende legitimar el latin lover Moreno. La caracterización de Elena como una mujer seductora dominadora y fatal, opuesta a la del ingeniero, acentúa la identidad heroica y racional del héroe masculino. Utilizando la sofisticación y su propia condición objetual, Elena revela cómo la continencia y la 
frustración masculina son los valores que han organizado la estructura social de Argentina.

Si bien la vamp consigue poner en entredicho la aparente bondad con la que se identifica la masculinidad, la imperturbabilidad de su amado va a reconvertir la suya imprevisiblemente. Aunque, en momentos específicos, Elena haya conseguido que Robledo tome conciencia de sí mismo como objeto de deseo, la masculinidad ejemplar del ingeniero le obliga a reencontrarse con una nueva feminidad benefactora y maternal. Esta transformación parece presagiarse en la secuencia en la que el rostro de Elena aparece deformado en el espejo. Pero el gran momento llega cuando Elena se acerca a un niño, que inesperadamente ha entrado en su dormitorio, y lo toma en sus brazos. En este instante, Elena ya es la mujer maternal que anhela su amado. Por último, la reconversión de la protagonista se produce cuando Robledo, después de pedirle que se marche de Argentina, tras las sucesivas desgracias que han ocurrido desde su llegada, acude de nuevo a la casa donde se encuentra Elena y en un arrebato de ira intenta estrangularla. En el momento de la agresión, un rayo de luz destella la faz del héroe y vuelve a dar forma al rostro desfigurado de la dama. Robledo le confiesa su amor incondicional y Elena, profundamente arrepentida, decide reprimir su poder erótico y acepta el asignado papel de esposa atenta que vela por la masculinidad activa de su amado. Así, esta feminidad maternal y benéfica es digna de ser ofrecida al Todopoderoso. Por eso en la última secuencia, Elena, en plena alucinación, entrega al vagabundo, creyendo que es Jesucristo, el rubí regalado por su amado, pues como Jesús, ahora, la angelical Elena va a morir de amor.

\section{Fotografía 19. De la vamp a la mujer maternal}

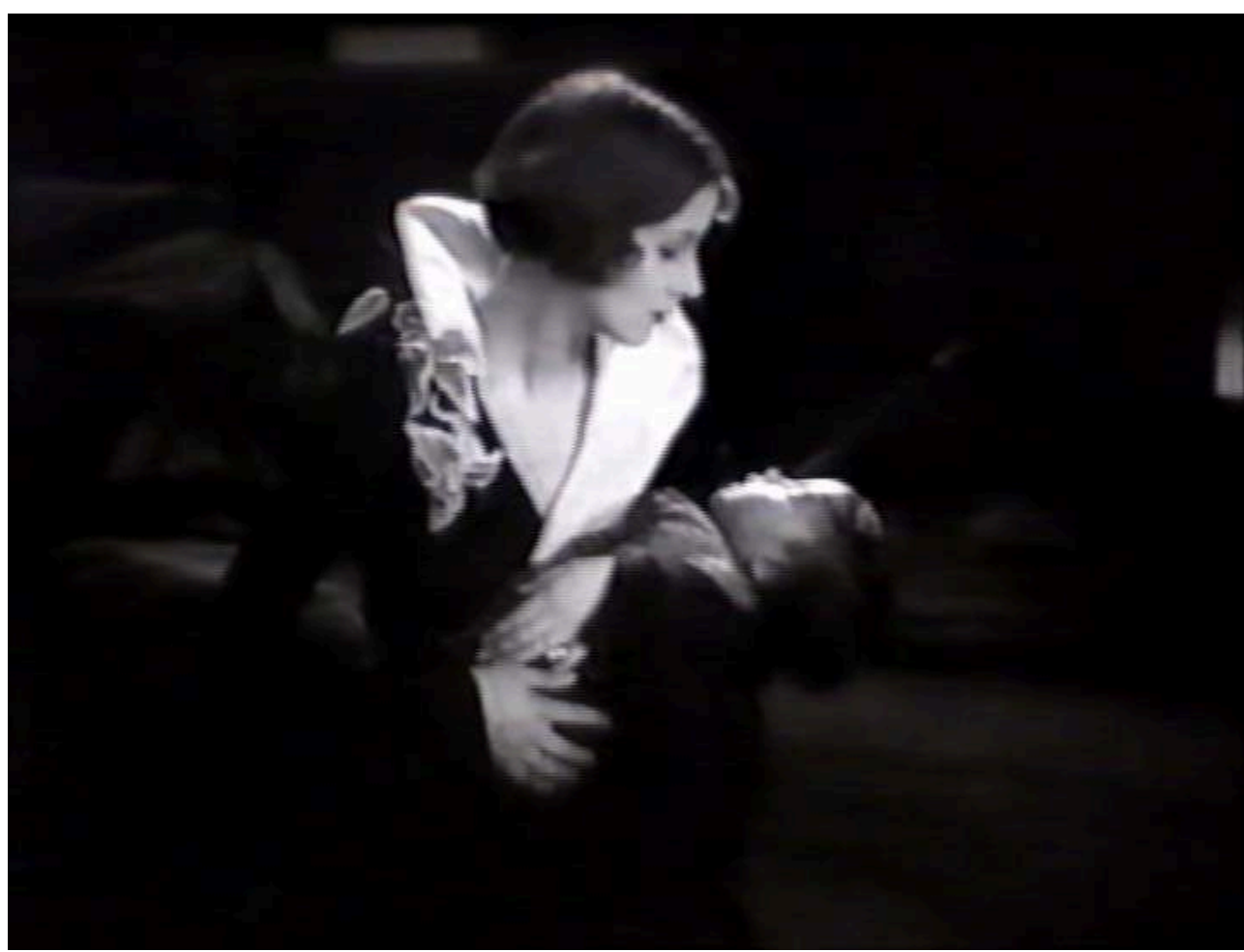

En este sentido, debemos interrogarnos sobre la relevancia que posee el descubrimiento de una nueva feminidad por parte de la vamp. Su transformación no se debe exclusivamente a la evolución interna del personaje, sino sobre todo al elixir que 
ha provocado dicho cambio, el héroe Robledo. Nos encontramos con un nuevo tipo de latin lover que ha dejado de ser vehículo reconciliador de feminidades ${ }^{28}$ y se ha encontrado con la obligación de convertirse en el terapeuta de la mujer fatal. Para entender la relevancia de esta permuta, hay que precisar que en el contexto cultural de finales de la década de los veinte, la Nueva Mujer ya es una realidad desestabilizadora. Los importantes cambios producidos en la idea de feminidad provocaron que el discurso predominante ${ }^{29}$, basado en que esta nueva mujer había introducido nuevos y ejemplares valores como, por ejemplo, "el verdadero matrimonio democrático", fuera suplantado por otros que categorizaban en compartimentos estancos a los dos modelos de feminismo - "Feminist New Style" frente a "Feminist Old Style" 30 - pretendiendo recuperar este último. Bajo el prisma de esta coyuntura histórica, se entiende la propia reconfiguración que Hollywood hace de su estereotipo, pues por medio de un modelo de subjetividad masculino que se propone como espectáculo visual y objeto de deseo parece más factible que se recupere a "The Feminist old Style" sin que se ponga de manifiesto su fin ideológico.

\section{Robledo, un latino occidentalizado}

La imagen de un ingeniero que es profundamente crítico con el París del progreso y a la vez capaz de inculcar a Argentina valores como la honradez, la valentía y el esfuerzo refleja el discurso étnico específico que articula el film.

Robledo encarna a un latino completamente opuesto a los rasgos con los que se escenifica Argentina. Este país se representa como un país subdesarrollado, salvaje y primitivo, sometido al bandolerismo despótico, mientras que Robledo se posiciona como un personaje ejemplar que introduce la idea de trabajo honrado, afín al ideal americano de que el éxito se consigue sólo trabajando fervientemente. De hecho, él es quien convierte a Argentina en un Estado que posee un presidente y donde las guitarras y las canciones populares se han transformado en trompetas y comparsas militares.

43 Robledo es el guía de un pueblo que no comparte ni sus valores ni su propia fisonomía. Mientras la apariencia de su gente denota pobreza y miseria (las mujeres no llevan zapatos, todos visten con harapos), el ingeniero expone su alta posición social tanto en el vestir (lleva botas específicas de montaña, camisas y pantalones de jinete) como en los modales. Inclusive en la indómita Argentina, Robledo siempre se despoja de su sombrero antes de hablar con la coqueta Elena, en oposición a la descortesía que muestra su gente. Otro de los rasgos que marcan la diferencia entre el héroe y la muchedumbre es el color de la piel. La blancura de su piel contrasta con el tono mestizo de la mayoría del pueblo argentino. Esta blancura es una de las cualidades que ha permitido que el estereotipo del latin lover sea interpretado por ciertos autores como un falso latino con rasgos mediterráneos ${ }^{31}$. Pero este rasgo se inscribe en el discurso racial que lleva parejo el personaje en tanto latino inteligente y poderoso, capaz de juzgar lo pernicioso de Europa y de civilizar a Latinoamérica.

Al mismo tiempo, el discurso étnico que sostiene el film se filtra sobre la historia de amor. Si bien resulta ya significativo que Robledo se enamore perdidamente de una mujer europea, aún es más relevante que éste acabe formalizando su noviazgo con una nativa, la bella Celinda. Este argumento subraya el rechazo al matrimonio mixto o mestizo que tanto miedo estaba suscitando en la época de producción del film. El lugar privilegiado que ocupaba en el imaginario popular la Nueva Mujer podía poner en 
peligro la pretendida pureza racial de la nación. Así, comenzaron a proliferar discursos en periódicos y revistas de mujeres, por ejemplo, en Ladies Home Journal o en Woman's Home Companion, que desaconsejaban los matrimonios de nacionalidades mixtas, promovían las historias de amor entre la gente de clase WASP y advertían sobre el suicidio de la raza que estaba suponiendo la llegada masiva de inmigrantes europeos. Por ejemplo, en Saturday Evening Post, en 1922, Kenneth Roberts proclamó que los matrimonios mixtos estaban produciendo "una raza híbrida de gente tan despreciable e inútil como los idiotas de Centroamérica y del Sudeste de Europa" ${ }^{32}$.

Fotografía 20. El latin lover, el otro étnico ideal

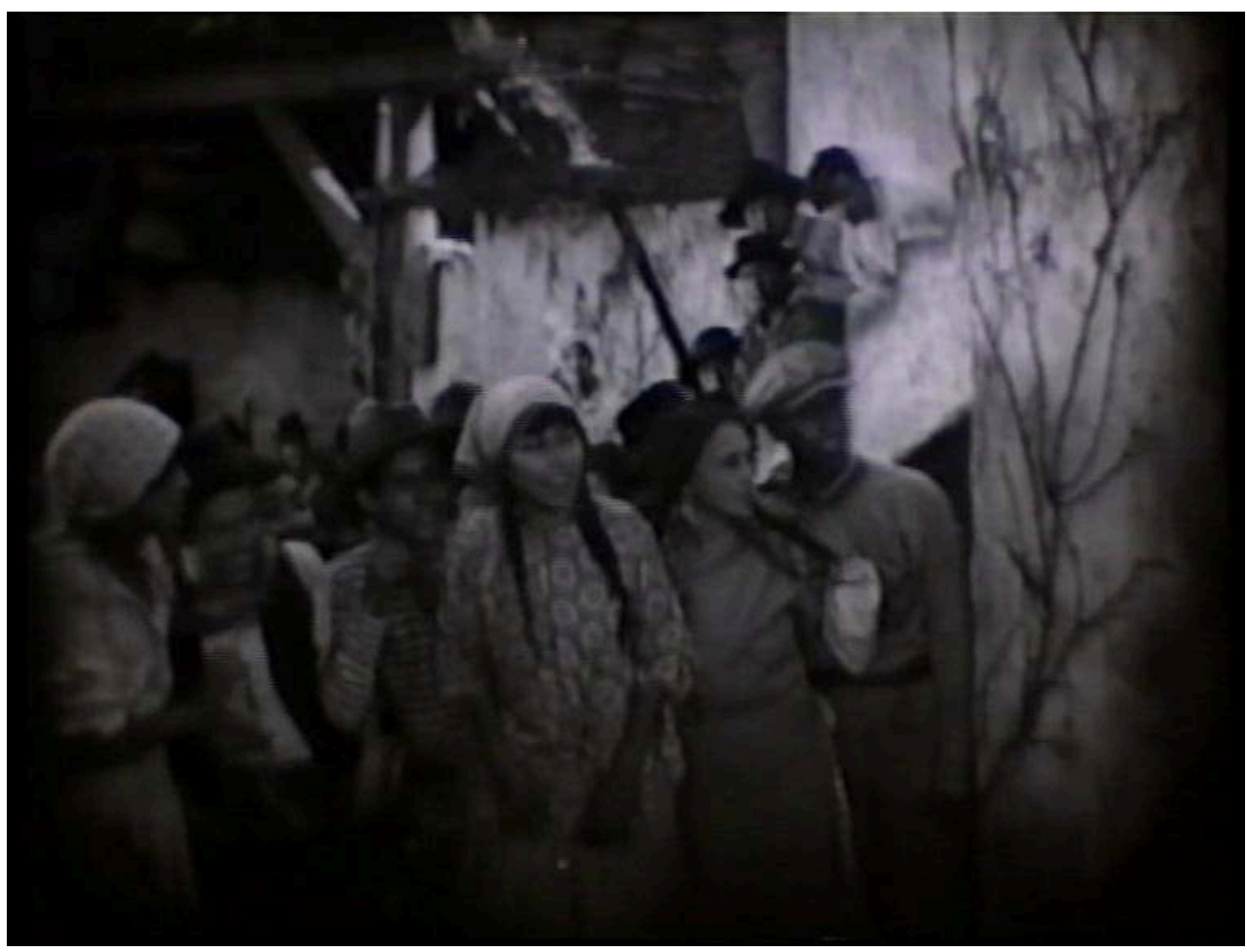


Fotografía 21. El latin lover, el otro étnico ideal

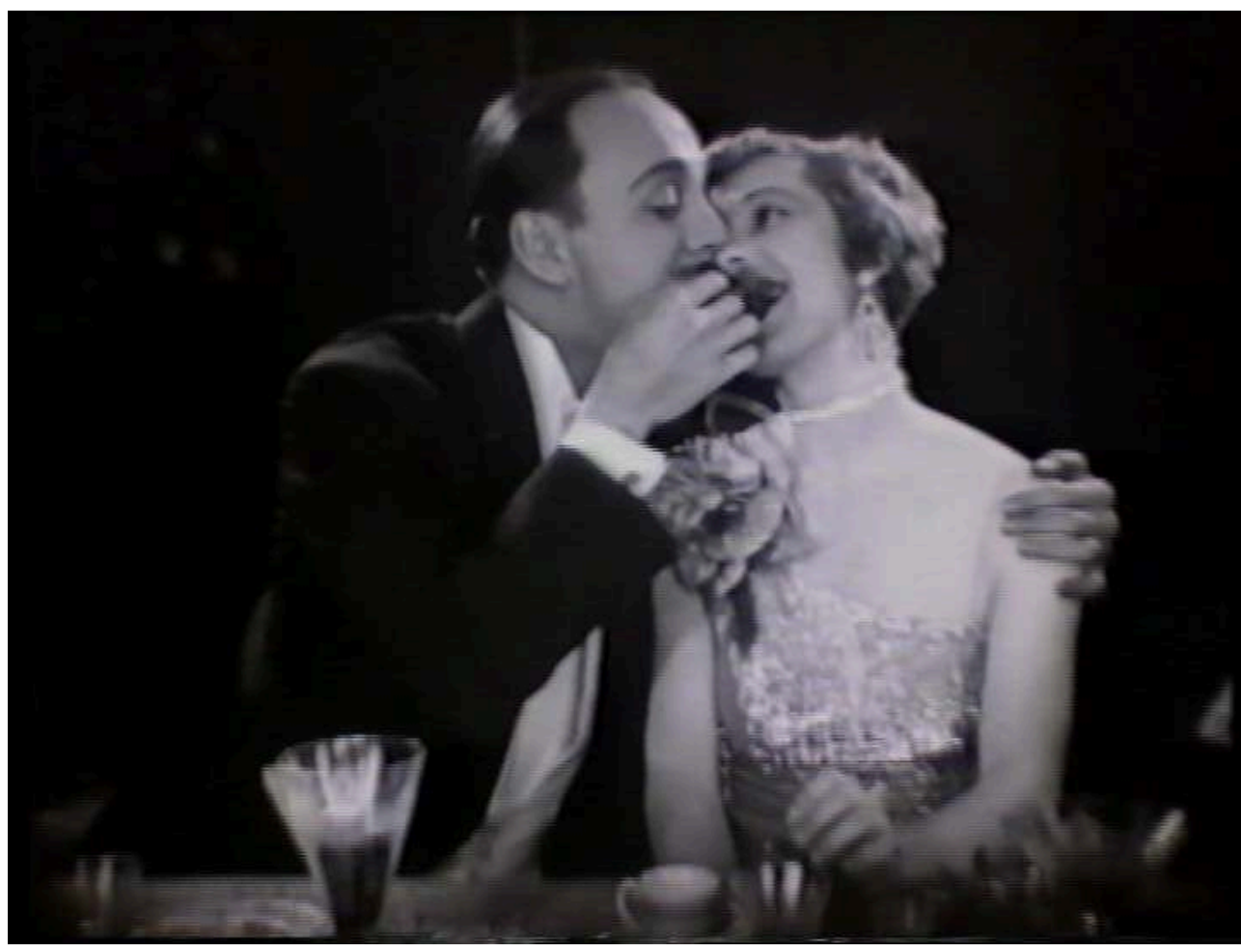

Retomando las diferencias existentes entre Robledo y Argentina, podemos hablar de Robledo como un otro que ni quiere ser un argentino pobre, sometido a la tiranía, ni quiere vivir en un París promiscuo. Este héroe, representante del progreso, se encuentra capacitado para ver la inmoralidad de un París liberal. Sus constantes viajes manifiestan el anhelo por un país imaginario donde triunfe la ley, el progreso racional, el trabajo honrado y el amor sosegado. Robledo es el otro étnico ideal, es decir el otro soñado por el "anglo" que simboliza el éxito americano y que cree firmemente en valores morales ajenos a los de su país. En definitiva, en The temptress asistimos a una manera eficaz de reconciliar los conflictos emergentes en la América multiétnica de los años veinte: la asimilación.

En conclusión, podemos afirmar que el latin lover Antonio Moreno encarna aquellos aspectos exigidos por la feminidad moderna y por una óptima "americanización" del inmigrante $\mathrm{y}$, por lo tanto, había que asignarle una marca de alteridad que oscilara entre el rechazo y la fascinación y que definiera a su otro: la mujer y el americano de los años veinte. Asimismo, los distintos pares de identidades que asume - objeto/sujeto de deseo, seducido/seductor - lo constituyen como símbolo representativo de una cultura que comercializa el placer y el deseo según la erótica del objeto de consumo. Una sociedad que vive en pleno auge económico, pero que siente su propia crisis y trata de resolverla creando a sus estrellas y figuras cinematográficas para que éstas ofrezcan determinados valores que la equilibren. 


\section{NOTAS}

1. Este artículo es la versión definitiva del trabajo presentado en el XI Congreso Internacional de la Asociación Española de Historiadores del Cine: “¿Savia Nutricia? El lugar del realismo en el cine español”, celebrado en Córdoba, febrero de 2006.

2. À l'ombre du latin lover: Antonio Moreno dans le cinéma hollywoodien des années vingt.Hollywood de los años veinte. El caso de The temptress (Fred Niblo, 1926).

3. Richard Dyer, Las estrellas cinematográfica, Barcelona, Paidós, 2001.

4. Edgar Morin, Les stars, Francia, Seuil, 1972.

5. Véase Philippe Berthier, "Del mito a la realidad" en Bricout, Benadette (comp.), La mirada de Orfeo. Los mitos literarios de Occidente, Barcelona, Paidós, 2002.

6. El latin lover coincide en el tiempo con la vigencia del estereotipo del greaser que ofrecía una imagen peyorativa del mexicano como persona sucia, violenta y mezquina. De ahí que en febrero de 1922, el gobierno mexicano prohibiera la exhibición de películas que retrataban a los mexicanos desfavorablemente.

7. Edgard Said, Orientalism, Barcelona, Debolsillo, 2003.

8. Joan Jordan, “Confessions of a modern Don Juan”, en Photoplay, mayo de 1921, p. 46.

9. Ibidem, p. 47.

10. Gaylyn Studlar, "Discourses of gender and ethnicity: the Construction and De(con)struction of Rudolph Valentino as Other", en Film Criticism, vol. XIII, ํㅡㄹ 2, 1989, p. 24.

11. Ibíd., p. 26.

12. Núria Bou; Xavier Pérez, El tiempo del héroe. Épica y masculinidad en el cine de Hollywood. Barcelona, Paidós, 2000, p. 23-36.

13. Sobre el nuevo hombre surgido después de la Revolución Industrial que perdurará durante las dos primeras décadas del siglo XX, véase Cortés, José Miguel G., Hombres de mármol. Códigos de representación y estrategias de poder de la masculinidad, Barcelona y Madrid, Egales, 2004, p. 92-110.

14. José Miguel G. Cortés, op. cit., p. 95.

15. Disentimos de Allen Woll en su idea de que la belleza del latin lover era latina, en la mayoría de los casos de descendencia italiana. Woll, Allen L, The latin image in American Film, Los Angeles, Ed. Ucla, 1980, p. 20.

16. Antonio Gramsci, Obras, T. 1, Notas sobre Maquiavelo, sobre Política y sobre el Estado Moderno. Visión, Madrid, 1980.

17. Véase como ejemplo el breve comentario sobre la star que aparecía en un artículo del perió dico Chicago Daily Tribune: "La boca y la barbilla pertenecen a un tipo nacido en un país que es famoso por hacer salvaje lo salvaje", Chicago Daily Tribune, 4 marzo de 1923, p. 29.

18. Photoplay, mayo de 1921.

19. Este tipo de belleza 'étnica' tiene bastantes puntos en común con la apariencia física de la estrella Dolores del Río. Considerada la "Rodolfo Valentino femenino", Dolores del Río poseía una belleza exótica y racial, pero que se mantenía dentro de los estándares europeos.

20. En opinión del periódico Chicago Tribune: "el instructor más influyente en la afeminada 'es cuela nacional de masculinidad' de Hollywood". "Powerd Puff", en Chicago Tribune, 18 de julio de 1926, p. 10. Citado por Anger, Kenneth, Hollywood Babylon, Nueva York, Bell, 1981, p. 107.

21. St. Johns, Adele Rogers, "What Kind of Men Attract Women Most?", en revista Photoplay, abril de 1924. Citado por Studlar, Gaylyn, art. cit., p. 20.

22. Dyer, Richard, The matter of images. Essays on Representation, Londres y Nueva York, Routledge, 2002, p. 14.

23. Fernández Vilches, Gloria, Las representaciones de Carmen en el cine norteamericano, Tesis doctoral, Universitat de València, 2007. 
24. Andrews, Benjamin R., "The Home Woman as Buyer and Controller of Consumption", en Annals, mayo de 1929, no 143, p. 41.

25. Photoplay, octubre de 1929.

26. En una misma entrevista Moreno declaraba: "las mujeres deberían ser discretas. La apariencia a menudo daña a una mujer tanto o más que el pecado", y contradictoriamente: "Está bien que ellas fumen cigarrillos si lo hacen con elegancia. Es como si nos lanzaran un beso". Jordan, Joan, art. cit., p. 46-47.

27. Harry M. Benshoff y Sean Griffin, America on Film. Representing Race, Class, Gender, and Sexuality at the Movies, Oxford, Blackwell Publishing, 2004, p. 138.

28. Este tipo de latin lover se distancia del de principios de la década que era capaz de reconciliar feminidades "opuestas" por medio de su ambivalencia. Un ejemplo a citar es el latin lover representado por la estrella Rodolfo Valentino en el film Sangre y Arena (Fred Niblo, 1922). Valentino interpreta a un torero que ama a dos mujeres aparentemente opuestas (su mujer Carmen y la vamp Doña Sol). El deseo por poseer a ambas mujeres y la anfibología del personaje se articula pensando en una posible reconciliación de feminidades.

29. Por ejemplo, en 1920, en el periódico Atlantic Monthly, un periodista explicaba: "antes sólo había una melodía en la casa de la esposa temblorosa; la melodía de la voz del amo, y, sin embargo, ahora el matrimonio se caracterizaba por su 'armonía polifónica'”. Citado por Brown, Dorothy M., Setting a Course. American Women in the 1920s, Boston, Twayne Publishers, 1987, p. 103.

30. Clasificación realizada por Dorothy Bromley en la revista Harper's, octubre de 1927. Citado por Brown, Dorothy M., op. cit., p. 110.

31. Autores como Woll, Allen L., op. cit., p. 20 y Keller, Gary D., Hispanics and United States Film: An Overview and Handbook, Tempe, AZ, Bilingual Review Press, 1994.

32. Roberts, Kenneth Lewis, Why Europe Leaves Home, Indianapolis, Arno Press, 1977 (1922). Citado en Studlar, Gaylyn, art. cit., p. 22.

\section{RESÚMENES}

El objeto de este artículo es analizar el discurso sexual y étnico que sostuvo la imagen de la estrella cinematográfica española Antonio Moreno en su paso por Hollywood. Ajustándose al estereotipo de latin lover, inaugurado por la estrella Rodolfo Valentino, la imagen de la star fuera y dentro de la pantalla funcionó como imagen de movilidad sexual en cuya anfibología-seductor y seducido, sujeto y objeto de deseo- se promovía la reconciliación entre viejos y nuevos valores emergentes en la sociedad norteamericana de los años veinte. Asimismo, su condición de estrella hispana fue promovida por la industria hollywoodiense para encauzar un discurso étnico ambivalente, en el que coexistía el rechazo y la fascinación. Es decir, la imagen de la estrella representaba a un otro ideal que simbolizaba el ideal de éxito americano al ser capaz de incorporarse a la cultura 'blanca', pero al mismo tiempo un otro considerado un 'hot blooded'. En este sentido, el estudio de textos que construyen la imagen pública del actor (carteles, publicidad, revistas de fans, etc.) y el análisis fílmico de la película The Temptress (Fred Niblo, 1926) permiten examinar cómo el latin lover Antonio Moreno representó un estereotipo sexual y étnico que contribuyó a definir el imaginario cultural de la sociedad norteamericana.

L'objet de cet article est l'étude du discours sexuel et ethnique qui a sous-tendu l'image de la star de cinéma Antonio Moreno, durant son passage à Hollywood. S'ajustant au stéréotype du latin 
lover, initié par Rodolfo Valentino, l'image de la star a fonctionné à l'écran et dans la vie, comme image de mobilité sexuelle dont l'ambivalence (séducteur/séduit, sujet/objet de désir) permettait de promouvoir la réconciliation entre les valeurs anciennes et les valeurs nouvelles qui émergeaient dans la société nord-américaine des années vingt. De même, sa condition de star hispanique fut soutenue par l'industrie hollywoodienne pour diffuser un discours ethnique ambivalent, dans lequel coexistaient rejet et fascination. L'image de la star représentait donc un autre «idéal » qui symbolisait l'idéal de la réussite américaine dans la mesure où il pouvait s'incorporer à la culture «blanche », tout en restant un " autre ", considéré comme 'hot blooded'. En ce sens, l'étude des textes qui élaborent l'image publique de l'acteur (affiches, publicité, revues de fanzines, etc.) et l'analyse filmique de The Temptress (Fred Niblo, 1926) permettent d'étudier la manière dont le latin lover Antonio Moreno a représenté un stéréotype sexuel et ethnique qui a contribué à définir l'imaginaire culturel de la société nord-américaine.

\section{ÍNDICE}

Mots-clés: star, étude, masculinité, genre, culture latine, cinéma

\section{AUTOR}

ROCÍO ALCALA DEL OLMO OLEA

Universitat de Valencia, España 